\title{
PENGARUH MODEL BLENDED LEARNING BERBANTUAN VIDEO ANIMASI TERHADAP KEMAMPUAN PEMECAHAN MASALAH DAN PEMAHAMAN KONSEP SISWA
}

\author{
I Gusti Putu Sudiarta, I Wayan Sadra
}

\author{
Jurusan Pendidikan Matematika, Universitas Pendidikan Ganesha, Jalan Udayana No. 11 Singaraja \\ email: sudiartagustiputu@gmail.com
}

\begin{abstract}
This study is part of a 2-years long-term study and is intended to evaluate the developed blended learning model using whiteboard animation video in a small scope of junior high school in the city of Singaraja. Two series of experiments conducted at grade 7 of SMPN 1 and SMPN 2 Singaraja. The school selection was based on the readiness criteria of ICT-infrastructure of the school as well as the readiness of teachers and students to use the blended learning technology. This study is a quasi-experimental research, with a post-test only control group design. The population is all students of grade 7 at SMP Negeri 1 and SMPN 2 Singaraja. The sample was selected by cluster random sampling technique. The first experiments carried out in SMP N 1 Singaraja by choosing the problem-solving skills as the dependent variable, while the second experiment was in SMPN 2 Singaraja and used the conceptual understanding as its dependent variable. The independent variable in both experiments was the developed blended learning model. The experimental results in SMPN 1 Singaraja show that mathematics problem-solving skill of students who follow the blended learning model is significantly better than those who take conventional learning. Likewise, the experimental results at SMP N 2 Singaraja show that the mathematical concept of students in the intervention class of is also higher than those in the conventional learning. It can be concluded that the implementation of developed blended learning models has a positive effect on the problem-solving skill and conceptual understanding of student grade 7 at Junior High School in the city of Singaraja. This is reasonable because students who take the blended learning became more active, better trained in discussions, more motivated and more excited to the learning process in compared with students who take the conventional learning.
\end{abstract}

Kata-kata Kunci: Blended Learning, Video Animasi, Kemampuan Pemecahan Masalah, Pemahaman Konsep.

\begin{abstract}
Abstrak: Penelitian ini merupakan bagian dari penelitian jangka panjang (2 tahun) yang mana tahapan ini merupakan tahapan ujicoba model pembelajaran yang dilakukan secara terbatas di SMP Negeri di Kota Singaraja. Dua seri penelitian ujicoba dilakukan dengan memilih 2 sekolah yaitu SMPN 1 dan SMPN 2 Singaraja, kelas VII yang dilakukan atas pertimbangan kriteria kesiapan perangkat TIK, serta kesiapan guru dan siswa dalam menggunakannya dalam pembelajaran. Penelitian ini merupakan penelitian eksperimen semu, dengan post-test only control group design, dan meliputi populasi seluruh siswa Kelas VII non unggulan baik di SMP Negeri 1, maupun di SMPN 2 Sngaraja. Pengambilan sampel dilakukan dengan teknik cluster random sampling. Experimen pertama dilakukan di SMP N 1 Singaraja dengan menggunakan variabel terikat kemampuan pemecahan masalah, sedangkan experimen kedua di SMPN 2 Singaraja dengan menggunakan varibel terikat pemahaman konsep. Sedangkan variabel bebasnya untuk kedua experimen itu adalah model pembelajaran, yaitu model pembelajaran blended learning berbasis video animasi untuk kelompok experimen dan pembelajaran konvensional untuk kelompok kontrol. Hasil Experimen di SMPN 1 Singaraja
\end{abstract}


menunjukkan bahwa kemampuan pemecahan masalah matematika siswa yang mengikuti blended learning berbasis video animasi lebih baik secara signifikan daripada kemampuan siswa yang mengikuti pembelajaran konvensional. Demikian juga dengan hasil experimen di SMP N 2 Singaraja menunjukkan bahwa kemampuan pemahaman konsep matematika siswa yang mengikuti blended learning berbasis video animasi lebih baik secara signifikan daripada pemahaman konsep siswa yang mengikuti pembelajaran konvensional. Dengan demikian dapat disimpulkan bahwa penerapan model blended learning berbantuan video animasi berpengaruh positif terhadap kemampuan pemecahan masalah dan pemahaman konsep siswa kelas VII di SMP Negeri di Kota Singaraja. Hal ini beralasan karena dukung oleh temuan lapangan bahwa siswa yang mengikuti blended learning berbantuan video animasi menjadi lebih aktif, lebih terlatih dalam berdiskusi, lebih termotivasi, dan lebih bersemangat dalam belajar matematika dibandingkan dengan siswa yang mengikuti pembelajaran konvensional.

Kata-kata Kunci: Blended Learning, Video Animasi, Kemampuan Pemecahan Masalah, Pemahaman Konsep.

Teknologi internet semakin berkembang pesat saat ini. Ketersediaan bandwidth semakin besar, mengakibatkan akses internet semakin cepat dan semakin murah. Hal ini memberikan peluang bagi segala bidang, tak terkecuali bidang pendidikan dan pembelajaran. Dalam konteks Indonesia, Jajaran Departemen Pendidikan, Dinas Pendidikan, sekolah-sekolah, bahkan guru-guru berusaha memanfaatkan ketersediaan internet ini untuk mendukung pendidikan dan pembelajaran. Namun sampai saat ini, boleh dikatakan belum ada model yang terukur dan teruji, bagaimana sekolah misalnya benar-benar bisa memanfaatkan kehadiran teknologi internet ini. Di sekolah-sekolah, pengunaan internet masih cenderung dipergunakan sebagai alat bantu, yang diterapkan secara sporadis, kadang-kadang berfungsi dan kadangkadang tidak. Pengunaan internet belum menjadi program yang sistematik yang berkelanjutan, sehingga hasil dan dampaknya pun belum bisa diukur dengan baik. Sebagian besar guru-guru juga masih kebingungan bagaimana mereka memanfaatkan teknologi internet untuk mendukung pembelajaran mereka. Di lain pihak, di era digital abad ke-21 ini pembelajaran matematika juga mengalami banyak perubahan dan membutuhkan kemampuan dalam menggunakan teknologi internet. Ketersediaan teknologi digital canggih telah mengubah cara berpikir tentang matematika dan bagaimana pembelajaran matematika yang efektif mestinya dilakukan. Aneka software pembuat video animasi yang tersedia gratis di internet dapat digunakan untuk menyajikan dan memvisualisasikan masalah matematika secara lebih nyata dan menantang, yang tujuannya untuk meningkatkan pemahaman konsep, penalaran, kemampuan pemecahan masalah, bahkan meningkatkan rasa ingin tahu dan kreativitas siswa. Konsep maupun keterampilan matematika yang disajikan dengan video animasi ini, dapat melibatkan siswa dalam berpikir dan melakukan aktivitas belajar matematika dengan lebih efektif, lebih cepat, dan lebih mendalam, dari pada cara tradisional yang dilakukan hanya dengan menggunakan membaca buku, maupun melalui pembelajaran tatap muka biasa di kelas (Jakaria, I Gusti Putu Sudiarta, \& Gede Suweken, 2014). Apalagi jika video animasi matematika ini disajikan dengan menggunakan pendekatan blended learning yaitu pendekatan pembelajaran campuran antara pembelajaran tatap muka biasa (classroom face-to face) dengan pembelajaran tatap muka dunia maya (online face-to face), dimana sumber pembelajaran, berupa uraian materi pembelajaran, tugas-tugas, maupun tes yang dapat berupa teks, gambar, suara, maupun video ditaruh di internet sehingga 
dapat diakses siswa 24 jam. YouTube misalnya adalah salah satu sumber yang kaya untuk klip video animasi dan film pendek yang akan menantang siswa untuk menonton dengan hati-hati dan terlibat dalam berpikir dan belajar matematika. Sumber yang kaya ini dapat dijadikan guru sebagai sumber pembelajaran dengan menggunakan pendekatan blended learning.

Di mancanegara kecenderungan penggunaan blended learning (bahkan online learning) semakin meningkat dalam beberapa tahun terakhir ini. Misalnya, Amerika Serikat telah memproyeksikan bahwa pada tahun 2014 lebih dari 80\% dari semua mahasiswa pada pendidikan tingginya mengambil sekurang-kurangnya satu mata kuliah online (Maarop \& Embi, 2016). Lebih jauh berdasarkan survei yang dilakukan oleh (Hilliard, 2015) bahwa blended learning telah mencapai pertumbuhan $46 \%$ per tahun di seluruh dunia. Sementara di Indonesia telah pula digalakkan pembelajaran berbasis TIK sejak lebih dari satu dasa warsa terakhir ini. Penetrasi penggunaan internet juga meningkat sangat pesat dalam tiga tahun terakhir ini, dari 22, 779 juta pada tahun 2013 menjadi 27, 233 juta pada tahun 2014 dan 32, 243 juta pada tahun 2015 (Demand Forecast Ditjen Postel, 2002). Berkaitan dengan pemanfaatan internet untuk blended learning di Indonesia, Zainuddin \& Halili (2016) menyatakan bahwa ada 20 artikel yang melaporkan penerapan blended learning dengan model flipped classroom dalam kurun waktu tahun 2013-2015. Hal ini menunjukkan bahwa potensi penerapan blended learning di Indonesia sangat tinggi dan menjanjikan dalam memberikan inovasi maupun sumbangan teoritis dan praktis dalam memecahkan masalah pembelajaran matematika di Indonesia. Namun sampai saat ini belum ada hasil penelitian mendalam dan literatur yang memadai dalam konteks Indonesia, yaitu misalnya:

(1) bagaimana model pembelajaran blended learning terbaik yang cocok untuk karakter siswa dan sekolah Indonesia,
(2) model blended learning yang mana yang paling efektif dan berpengaruh positif terhadap kompetensi esensial matematika, seperti (a) kemampuan pemahaman konsep, (b) kemampuan penalaran, (c) kemampuan pemecahan masalah, (d) kemampuan koneksi matematis, dan (e) kemampuan resprentasi matematis siswa.

(3) model blended learning yang mana yang paling efektif dan berpengaruh positif terhadap karakter esensial siswa, seperti terhadap sikap kerja keras, kejujuran, rasa ingin tahu, bahkan rasa kagum terhadap matematika.

Berdasarkan rasional ini, maka peneliti memandang sangat penting untuk mengadakan penelitian berjudul "Pengaruh Penerapan Blended Learning Berbantuan Video Animasi (BLBVA) Terhadap Pemahaman Konsep dan Kemampuan Pemecahan Masalah Matematika Siswa SMP di Kota Singaraja", yang mana penelitian ini merupakan bagian dari sebuah penelitian pengembangan selama dua tahun yaitu 2015-2017 yaitu penelitian pada tahapan uji coba model. Video Animasi (VA) dalam penelitian ini adalah White Board Animation Video (WBAV) yang dibuat menggunakan suatu software animasi, dipilih sebagai basis dalam penelitian ini, karena dapat digunakan untuk mempresentasikan konsep dan keterampilan matematika secara audiovisual, yang memuat teks, gambar dan animasi yang menarik, sehingga (a) dapat digunakan untuk mempresentasikan konsep-konsep sulit dengan lebih jelas dan menarik, (b) dapat digunakan untuk memberikan ilustrasi yang menarik dan kontektual pada konsep-konsep matematika yang cenderung kering dan membosankan, (c) dapat meningkatkan keterlibatan siswa dalam pembelajaran serta meningkatkan pemahaman dan keterampilan matematika siswa. 


\section{METODE}

Penelitian ini merupakan bagian dari penelitian jangka panjang (2 tahun) yang mana tahapan ini merupakan tahapan ujicoba model pembelajaran blended learning yang dilakukan secara terbatas di SMP Kota Singaraja. Dua seri penelitian ujicoba dilakukan dengan memilih 2 sekolah yaitu SMPN 1 dan SMPN 2 Singaraja, kelas VII yang dilakukan atas pertimbangan kriteria kesiapan perangkat teknologi informasi dan komunikasi (TIK), serta kesiapan guru dan siswa dalam menggunakannya dalam pembelajaran. Dua orang mahasiswa yang sedang menyusun skripsi dilibatkan dalam research grant dan dua orang guru dilatih untuk melaksanakan blended learning dan mempersiapkan video animasi matematika secara teliti. Penelitian ini merupakan penelitian eksperimen semu, dengan post-test only control group design, dan meliputi populasi seluruh siswa Kelas VII non unggulan baik di SMP Negeri 1, maupun di SMPN 2 Singaraja. Pengambilan sampel dilakukan dengan teknik cluster random sampling dari populasi yang sudah diuji kesetaraannya dengan ANAVA satu jalur sehingga akan ada dua kelas sebagai sampel yang akan diundi lagi untuk menentukan satu kelas kontrol dan dua kelas eksperimen. Experimen pertama dilakukan di SMPN 1 Singaraja dengan menggunakan variabel terikat kemampuan pemecahan masalah, sedangkan experimen kedua di SMPN 2 Singaraja dengan menggunakan varibel terikat pemahaman konsep. Sedangkan variabel bebasnya untuk kedua experimen itu adalah model pembelajaran, yaitu model BLBVA untuk kelompok experimen dan pembelajaran konvensional untuk kelompok kontrol.

Data pada penelitian ini berupa skor pemecahan masalah dan pemahaman konsep siswa dikumpulkan masingmasing dengan menggunakan tes kemampuan pemecahan masalah dan tes pemahaman konsep. Setelah kelompok sampel diberi perlakuan, dilakukan pengujian terhadap hipotesis yang diajukan. Terlebih dahulu, data yang diperoleh dilakukan pengujian normalitas sebaran data dengan Uji Kolgomorov Smirnov dan pengujian homogenitas varians dengan uji Levene. Selanjutnya pengujian hipotesis dilakukan dengan uji-t dengan taraf signifikan $5 \%$.

\section{HASIL DAN PEMBAHASAN}

Hasil

\section{Experimen di SMP Negeri 1 Singaraja}

Data mengenai kemampuam pemecahan masalah matematika siswa yang diperoleh dari post-test yang diberikan kepada kedua kelas sampel dapat dilihat pada Tabel 1.

Hasil pengujian normalitas sebaran data kemampuam pemecahan masala matematika siswa dengan Uji Kolgomorov Smirnov adalah sebagai berikut: $D_{\text {hitung }}$ pada kelas eksperimen adalah 0,18253 dan $D_{\text {hitung }}$ pada kelas kontrol adalah 0,21676. Sementara itu $D_{\text {tabel }}$ untuk kelas eksperimen adalah 0.2236 dan kelas kontrol adalah 0,2206 pada taraf signifikasi 5\%. Dari perhitungan tersebut menunjukkan masingmasing $D_{\text {hitung }}$ pada kedua kelas sampel lebih kecil dari $D_{\text {tabel }}$ pada kelas sampel yang bersangkutan. Dengan demikian $\mathrm{H}_{0}$ diterima yang berarti kedua kelas sampel memiliki data yang berdistribusi normal.

Tabel 1. Rangkuman Analisis Data Kemampuan Pemecahan Masalah Matematika

\begin{tabular}{cccc}
\hline \multirow{2}{*}{ No } & \multirow{2}{*}{ Variabel } & \multicolumn{2}{c}{ Kelas Sampel } \\
\cline { 3 - 4 } & & $\mathrm{E}$ & $\mathrm{K}$ \\
\hline 1. & $N$ & 37 & 38 \\
2. & $\bar{Y}$ & 91,216 & 82,631 \\
3. & $S D$ & 6,49 & 5,29 \\
\hline
\end{tabular}

Selanjutnya, hasil perhitungan homogenitas varians data kemampuam pemecahan masalah matematika siswa dengan uji Levene menunjukkan nilai $W=$ 1,5069 dan $F_{\text {tabel }}=1,7341$. Kemudian, nilai $W$ dibandingkan dengan nilai $F_{\text {tabel }}$ dan diperoleh nilai $W$ lebih kecil dari nilai $F_{\text {tabel}}$. Dengan demikian $\mathrm{H}_{0}$ diterima dan disimpulkan bahwa kedua kelas sampel memiliki varians data yang homogen. 
Selanjutnya, uji hipotesis dapat dilakukan dengan Uji-t adapun rangkuman hasil pengujian hipotesis adalah sebagai berikut.

Tabel 2: Rangkuman Hasil Pengujian Hipotesis

\begin{tabular}{cccccccc}
\hline Kelompok & $\mathrm{N}$ & $\bar{X}$ & $\mathrm{~S}^{2}$ & $\mathrm{~S}$ & $S_{\text {gab }}^{2}$ & $t_{\text {hitung }}$ & $t_{\text {tabel }}$ \\
\hline Eksperimen & 37 & 91,216 & 42,229 & 6,498 & & & \\
\cline { 1 - 5 } Kontrol & 38 & 82,631 & 28,022 & 5,293 & & 6,2801 & 1,9929
\end{tabular}

Dari perhitungan pada tabel kerja di atas, diperoleh $\mathrm{t}_{\text {hitung }}=6,2801$ dan $\mathrm{t}_{(0,95)(73)}=$ 1,9929. Apabila dibandingkan, nilai $t_{h i t} \geq t_{(1-\alpha)}$, sehingga $H_{0}$ ditolak. Hal ini berarti bahwa kemampuam pemecahan masalah matematika siswa yang mengkuti BLBVA lebih baik daripada kemampuam pemecahan masalahmatematika siswa yang mengikuti pembelajaran konvensional.

\section{Experimen di SMP Negeri 2 Singaraja}

Data mengenai kemampuam pemahaman konsep matematika siswa yang diperoleh dari post-test yang diberikan kepada kedua kelas sampel dapat dilihat pada Tabel 3 berikut.

\section{Tabel 3. Rangkuman Analisis Data Pemahaman Konsep Matematika Siswa}

\begin{tabular}{cccc}
\hline \multirow{2}{*}{ No } & \multirow{2}{*}{ Variabel } & \multicolumn{2}{c}{ Kelas Sampel } \\
\cline { 2 - 4 } & & $\mathrm{E}$ & $\mathrm{K}$ \\
\hline 1. & $N$ & 28 & 28 \\
2. & $\bar{Y}$ & 92,64 & 84,36 \\
3. & $S D$ & 5,83 & 7,36 \\
\hline
\end{tabular}

Hasil pengujian normalitas sebaran data Kemampuam Pemahaman Konsep
Matematika siswa dengan Uji Kolgomorov Smirnov adalah sebagai berikut: $D_{\text {hitung }}$ pada kelas eksperimen adalah 0,157 dan $D_{\text {hitung }}$ pada kelas kontrol adalah 0,128 . Sementara itu $D_{\text {tabel }}$ untuk kelas eksperimen dan kontrol adalah 0,250 pada taraf signifikasi $5 \%$. Dari perhitungan tersebut menunjukkan masing-masing $D_{\text {hitung }}$ pada kedua kelas sampel lebih kecil dari $D_{\text {tabel }}$ pada kelas sampel yang bersangkutan. Dengan demikian $\mathrm{H}_{0}$ diterima yang berarti kedua kelas sampel memiliki data yang berdistribusi normal.

Selanjutnya, hasil perhitungan homogenitas varians data Kemampuam Pemahaman Konsep Matematika a dengan uji Levene menunjukkan nilai $W=1,59232$ dan $F_{\text {tabel }}=1,90482 \quad$ Kemudian, nilai $W$ dibandingkan dengan nilai $F_{\text {tabel }}$ dan diperoleh nilai $W$ lebih kecil dari nilai $F_{\text {tabel }}$. Dengan demikian $\mathrm{H}_{0}$ diterima dan disimpulkan bahwa kedua kelas sampel memiliki varians data yang homogen.

Selanjutnya, uji hipotesis dapat dilakukan dengan Uji-t adapun rangkuman hasil pengujian hipotesis adalah sebagai berikut.

Tabel 4. Rangkuman Hasil Pengujian Hipotesis

\begin{tabular}{cccccccc} 
Kelompok & $\mathrm{N}$ & $\bar{X}$ & $\mathrm{~S}^{2}$ & $\mathrm{~S}$ & $S_{\text {gab }}^{2}$ & $t_{\text {hitung }}$ & $t_{\text {tabel }}$ \\
\hline Eksperimen & 28 & 92,643 & 34,015 & 5,323 & & & \\
\cline { 1 - 6 } Kontrol & 28 & 84,357 & 54,164 & 7,359 & & 4,669 & 2,0048 \\
\hline
\end{tabular}

Dari perhitungan pada Tabel 4, diperoleh $\mathrm{t}_{\text {hitung }}=4,669$ dan $\mathrm{t}_{(0,95)(73)}=2,004$. Apabila dibandingkan, nilai $t_{h i t} \geq t_{(1-\alpha)}$, sehingga $H_{0}$ ditolak. Hal ini berarti bahwa
Kemampuam Pemahaman Konsep Matematika siswa yang mengkuti BLBVA lebih baik daripada Kemampuan Pemahaman Konsep Matematika siswa 
yang mengikuti pembelajaran konvensional.

\section{Pembahasan}

Hasil penelitian ini sangat beralasan dan dapat dijelaskan sbb:

\section{a. Aktivitas Pembelajaran Online Didukung oleh Penjelasan Materi Pembelajaran Melalui Video Yang Menarik}

Design BLBVA yang digunakan dalam penelitian ini adalah Flipped Method yaitu yang menyediakan materi pembelajaran dalam bentuk Video animasi atau Whiteboad Animatioan Video (WAV) yang memuat penjelasan materi secara expositori. Materi ini disediakan di Website yang dapat diakses oleh siswa kapan saja selama 24 jam. Hal ini sangat membantu siswa kelompok experimen dalam dua hal yaitu (a) fleksibilitas dalam hal waktu dan tempat belajar, juga dalam hal seringnya video pembelajaran tersebut dicermati. Siswa dapat mengulangulang penjelasan materi WAV tersebut sebanyak mungkin yang dia mau. (b) Penjelasan materi pembelajaran melalui WAV secara terstruktur dan menggunakan pendekatan expositoris dialogis sangat membantu siswa dalam memahami materi dengan baik. Dua hal ini memberikan kepercayaan diri pada siswa, sehingga mereka lebih siap dalam mengikuti pembelajaran tatap muka di kelas. Sedangkan siswa pada kelas konvensional, seperti pembelajaran pada umumnya yang berbasis tatap muka saja, dengan sumber pelajaran wajibnya berupa buku-buku saja, walaupun sumber belajar dari internet tetap disarankan, tetapi tak terstruktur dan tak diarahkan secara memadai berdasarkan tujuan pembelajaran. Hal ini tentu tentu tidak menguntungkan terutama bagi siswa yang gampang bosan memahami materi pelajaran dari buku-buku saja.

\section{b. Diskusi Online Yang Membangun Kepercayaan dan Rasa Ingin Tahu Siswa}

Pembelajaran BLBVA pada kelas experimen memberikan kesempatan kepada siswa untuk berdiskusi, dan tanya jawab mengenai materi pembelajaran secara bebas. Hal ini memberikan ruang yang luas bagi siswa untuk mengutarakan pikiran, pendapat, perasaan, maupun masalah-masalah yang dihadapi berkaitan dengan materi pelajaran. Sering siswa bertanya apa adanya dengan kalimat yang sederhana dan polos, tetapi menunjukkan rasa ingin tahu dan kepercayaan diri mereka yang meningkat. Dengan adanya diskusi online dapat melatih siswa untuk melakukan tukar pendapat sehingga setiap siswa mempunyai kesempatan untuk menyampaikan atau mengkomunikasikan ide-idenya serta memberikan pertimbangan kepada siswa lain dalam memutuskan solusi masalah yang dihadapi. Selain itu, siswa juga dapat dengan mudah mencari bantuan dari temannya sehingga siswa tidak mudah menyerah dan lebih termotivasi dalam memecahkan masalah. Di samping itu siswa merasa lebih nyaman dalam komunikasi melalui pembelajaran online, karena semua pernyataan dan pertanyaan menjadi dapat dipikirkan dan direnungkan lebih dulu sebelum diposting, dibandingkan dengan komunikasi spontan lewat pembelajaran tatap muka.

Sedangkan pada kelas konvensional, diskusi sering menjadi tidak mudah dan mengalami kendala dalam menumbuhkan keberanian siswa dalam diskusi dalam pembelajaran tatap muka di kelas. Diskusi sering tidak lancar, karena siswa yang tidak siap, kurang percaya diri dan malu. Diskusi pun masih sangat terbatas oleh waktu dan tidak semua siswa memiliki kepercayaan diri yang cukup untuk berani bertanya maupun menanggapi pertanyaan siswa lainnya. 


\section{c. Aktivitas Pembelajaran Tatap Muka yang Berfokus pada Pemecahan Masalah}

Pembelajaran tatap muka pada kelas experimen berfokus pada pemecahan masalah dilanjutkan dengan presentasi siswa, untuk merangsang dan meningkatkan kemampuan pemecahan masalah maupun pemahaman konsep. Pembelajaran nampak lebih bermakna dan berlangsung lebih bergairah, lebih semangat, dan lebih terarah, waktu untuk kegiatan pemecahan masalah maupun kegiatan pemahaman konsep tersedia lebih banyak, akibatnya lebih banyak konsep yang dapat dibahas, dan lebih banyak masalah matematika yang dapat dipecahkan siswa. Hal ini nampaknya disebabkan karena sebagian besar siswa sudah mempersiapkan diri dengan lebih baik, karena mereka sudah mencermati video pembelajaran secara online, sehingga pada pertemuan tatap muka mereka lebih siap bekerja untuk memecahakan masalah-masalah matematika yang diberikan. Dalam hal ini nampak bahwa siswa lebih siap dalam melaksanakan tugas pemecahan masalah, dan lebih memahami konsekonsep matematika secara lebih luas dan lebih utuh. Pembelajaran tatap muka pun berakhir dengan tuntas, disertai dengan refleksi yang baik tentang apa yang sudah dicapai hari ini, maupun tentang apa yang akan dicapai berikutnya. Sedangkan pada kelas konvensional, siswa masih memerlukan waktu untuk memahami materi pembelajaran lebih dulu dari membaca buku maupun LKS, masih meraba-raba bagaimana teori dan konsep matematika yang akan dipelajari dapat digunakan dalam pemecahan masalah. Nampak bahwa siswa kurang siap, kurang memahami konsep matematika yang dipelajari secara utuh, dan masih ragu dalam menyelesaikan masalah matematika yang diberikan. Waktu terasa sangat kurang, sering hasilnya dicapai dengan seadanya. Hal ini sering berimplikasi pada berakhirnya pembelajaran tatap muka yang tidak sepenuhnya tuntas, disertai dengan refleksi yang memadai. Hal ini biasanya diatasi dengan melakukan himbauan agar siswa melanjutkan pembelajarannya di rumah, dan memberikan pekerjaaan rumah (PR) dalam jumlah banyak. Sementara itu kesempatan siswa untuk mengulangi konsep yang belum dipahami hanya bisa dilakukan dengan mengulang membaca buku saja, tidak ada video terstuktur yang bisa dijadikan panduan, tidak ada diskusi online tempat mereka bertanya.

Secara umum dapat disampaikan bahwa berdasarkan pembelajaran yang telah dilakukan, penerapan BLBVA dapat membuat (1) siswa memiliki kesempatan lebih banyak dalam memanfaatkan pengetahuan dan keterampilan matematika yang telah dimiliki, (2) siswa berpartisipasi aktif dalam pembelajaran dan aktif mengekspresikan ide-idenya, (3) siswa dapat merespon permasalahan dengan cara mereka sendiri, (4) siswa termotivasi untuk memberikan bukti atau penjelasan dari strategi yang dipilih dalam menyelesaikan permasalahan, (5) pengalaman siswa lebih banyak dalam menjawab permasalahan sehingga dapat meningkatkan pemahaman konsepnya. Hasil tersebut mendukung terjadinya peningkatan pemahaman konsep dan kemampuam pemecahan masalah matematika siswa.

Sejalan dengan hasil penelitian ini, dapat dijelaskan beberapa hasil penelitian internasional terbaru pun menunjukkan hasil yang positif terhadap penggunaan blended maupun online learning terhadap sikap, minat, prestasi dan kreativitas siswa dalam belajar matematika, antara lain:

a. Umoh \& Akpan (2014) menunjukkan manfaat penggunaan blended $e$ learning dalam meningkatkan sikap dan kepercayaan diri siswa dalam belajar matematika. Hal ini sejalan dengan temuan penelitian ini, bahwa model BLBVA memberikan kesempatan kepada siswa untuk berdiskusi, dan tanya jawab mengenai materi 
pembelajaran secara bebas. Siswa lebih berani mengutarakan pikiran, pendapat, perasaan, maupun masalah-masalah yang dihadapi berkaitan dengan materi pelajaran.

b. Vaughan, (2010) menunjukkan bahwa dalam konteks pembelajaran sekolah, penggunaan teknologi pembelajaran online menawarkan beberapa keunggulan dibandingkan dengan pembelajaran tatap muka. Berbeda dengan komunikasi verbal spontan pada lingkungan belajar tatap muka biasa, lingkungan belajar blended learning di mana komunikasi tertulis terjadi secara asynchronous dapat memberikan kondisi yang mempromosikan pertanyaan reflektif. Hal ini sejalan dengan temuan penelitan bahwa Siswa lebih berani bertanya apa adanya dengan kalimat yang sederhana dan polos, tetapi menunjukkan rasa ingin tahu dan kepercayaan diri mereka yang meningkat.

c. Khan (2013; 21-27) menunjukkan bahwa video-vedeo pembelajaran matematika online memberikan kepada siswa pengalaman yang aman, personal, nyaman dan menggugah pikiran. Sehingga pada akhirnya siswa dapat mengalamai momen-momen "Aha", di mana siswa yakin dapat memahami konsep matematika dengan mendalam". Hal ini diperkuat oleh temuan penelitian ini bahwa sebagian besar siswa sudah mempersiapkan diri dengan lebih baik, karena mereka sudah mencermati video pembelajaran secara online, sehingga pada pertemuan tatap muka mereka lebih siap bekerja untuk memecahakan masalah-masalah matematika yang menjadi lebih bermakna dan berlangsung lebih bergairah, lebih semangat, dan lebih terarah. Demikian juga dengan waktu untuk kegiatan pemecahan masalah maupun kegiatan pemahaman konsep tersedia lebih banyak, akibatnya lebih banyak konsep yang dapat dibahas, dan lebih banyak masalah matematika yang dapat dipecahkan siswa. WAV dalam penelitian ini digunakan untuk menyajikan masalah matematika yang menantang untuk siswa. Melalui visualisasi dan animasi konsep matematika, maupun prosedur matematika dapat disajikan menjadi lebih menarik, lebih jelas dan lebih mudah bagi siswa. Mengamati, mencatat, menganalisis, merefleksikan kejadian di $W A V$, pembelajaran matematika dapat memberikan kesempatan kepada siswa untuk belajar matematika dalam menyajikan pernyataan matematika dengan notasi, symbol, tabel, gambar, diagram dengan tepat, menyusun dugaan, atau konjektur matematis yang masuk akal, melakukan manipulasi matematis dengan akurat, menunjukkan bukti, memberikan argumen terhadap terhadap suatu langkah matematis yang tepat, memeriksa kesalahan suatu argumen matematis secara teliti, menarik kesimpulan berdasarkan pernyataan, bukti matematis yang relevan, serta membuat generalisasi berdasarkan pola, sifat maupun rangkaian langkah sistematis.

d. Abramovitz, Berezina, Berman, \& Shvartsman (2012) menujukkan bahwa belajar matematika melalui bantuan sumber online seperti video, animasi konsep matematika yang relevan dan menantang dapat meningkatkan rasa ingin tahu siswa, walaupun tidak secara signifikan data statistik menunjukkan Kemampuam Pemecahan Masalah matematika yang berbeda dengan kelas pembelajaran tatap muka biasa. Hal ini memerlukan penelitian pendalaman lebih lanjut. Namun dinyatakan pula, bahwa baik siswa dan guru merasa lebih nyaman dalam komunikasi asynchronous melalui pembelajaran online, karena semua pernyataan dan pertanyaan menjadi lebih bermakna dan reflektif, dari pada komunikasi spontan lewat pembelajaran tatap muka. Pada penelitian ini, Pembelajaran BLBVA dimulai dengan guru menanyakan kepada siswa, apakah mereka sudah mencermati video animasi yang dimaksud dalam materi yang akan dipelajari. Guru memberikan kesempatan kepada siswa untuk 
mengutarakan perasaan dan pendapat mereka mengenai video animasi yang telah mereka cermati di rumah. Dalam hal ini siswa diberikan kesempatan untuk dapat mengutarakan perasaan, pendapat, dan pikiran secara kritis terhadap apa yang telah mereka lihat dan pelajari di rumah secara online melalui web yang disediakan. Hal ini memberikan hasil yang mengembirakan bahwa sebagian siswa menjadi lebih kritis, lebih hati-hati, lebih terbuka dalam bertanya. Siswa lebih berani bertanya dengan cara yang bervariasi dan lebih berani menjawab pertanyaan, tanpa harus dihantui oleh rasa takut salah atau disalahkan.

e. Sementara di Indonesia penelitian mengenai penggunaan blended learning dalam pembelajaran matematika masih sangat terbatas. Salah satu yang dapat penulis temukan adalah (Pradnyawati, Suparta, \& Sariyasa, 2014) melalui penelitian Pengaruh Strategi Blended Learning Dalam Pembelajaran Kooperatif Terhadap Motivasi Belajar Matematika Ditinjau Dari Gaya Belajar Siswa Di SMP K 2 Harapan, Badung menemukan bahwa motivasi belajar matematika siswa yang dibelajarkan dengan pembelajaran kooperatif berbantuan strategi blended learning lebih baik daripada motivasi belajar matematika siswa yang dibelajarkan dengan pembelajaran kooperatif, dan terdapat interaksi antara strategi pembelajaran blended learning dan gaya belajar terhadap motivasi belajar siswa. Karena peningkatan motivasi dapat dikaitkan secara teoritis dengan peningkatan pemahaman konsep dan kemampuan pemecahan masalah, maka hal ini juga selaras dengan hasil penelitian ini bahwa BLBVA secara signifikan berpengaruh positif terhadap pemahaman konsep dan kemampuan pemecahan masalah siswa.

Terlepas dari hasil penelitian yang secara positif menunjukkan bahwa model BLBVA memberikan hasil yang lebih baik dalam hal kemampuan pemecahan masalah, dan pemahaman konsep siswa dan beberapa hal lain yang disebutkan sebelumnya, perlu juga dipaparkan mengenai tantangan dan tingkat kesulitan yang dihadapi guru dalam melaksanakan model BLBVA dalam konteks penelitian ini, misalnya seperti keengganan guru dalam mencoba inovasi yang baru, kurangnya keterampilan guru dalam menyiapkan materi pembelajaran terutama dalam bentuk video, rendahnya keterampilan guru dalam mengelola website, maupun mengelola diskusi online. Keberhasilan blended learning tentu saja sangat tergantung dari penyediaan infrastruktur pembelajaran online yang baik, dan skenario bagaimana menjadikan materi dan aktivitas pembelajaran online mendapatkan prioritas sama pentingnya dengan pembelajaran tatap muka biasa. Untuk itu sangat disarankan sebelum melaksanakan pembelajaran blended learning melakukan persiapan secara sungguh-sungguh meliputi (a) peningkatan kapasitas infrastruktur pembelajaran online oleh sekolah, (b) meningkatkan kemampuan guru dalam mempersiapkan materi pembelajaran online seperti text, video, animasi dan sebagainya sebagai materi utama yang bisa dipelajari siswa secara online dan yang berorientasi pada pencapaian tujuan pembelajaran, dan tentunya gayut dengan pembelajaran tatap muka sebagai kelanjutan dari pembelajaran onlinenya. (c) Di samping itu, pembelajaran blended juga perlu jadikan sarana belajar bersama oleh guru-guru secara kolegial, karena itu sangat disarankan jika penerapan blended learning ini dikombinasikan dengan prinsip-prinsip lesson study.

\section{SIMPULAN}

Berdasarkan hasil penelitian dan pembahasan yang telah diuraikan sebelumnya, dapat disimpulkan bahwa pemahaman konsep matematika dan kemampuam pemecahan masalah siswa yang mengikuti model BLBVA lebih baik daripada pemahaman konsep matematika dan kemampuam pemecahan masalah siswa yang mengikuti pembelajaran 
konvensional. Oleh karena itu model pembelajaran BLBVA berpengaruh positif terhadap kemampuam pemecahan masalah dan pemahaman konsep matematika siswa. Hal ini didukung oleh temuan lapangan bahwa siswa yang mengikuti BLBVA lebih aktif, memiliki rasa ingin tahu lebih tinggi, lebih termotivasi, dan bersemangat dalam belajar matematika dibandingkan dengan siswa yang mengikuti pembelajaran konvensional.

Adapun saran yang dapat disampaikan berdasarkan hasil penelitian yang telah dilakukan adalah sebagai berikut. (1) Kepada praktisi pendidikan, khususnya yang terlibat dalam pembelajaran matematika diharapkan dapat menggunakan pendekatan BLBVA sebagai salah satu alternatif model pembelajaran yang dapat diterapkan di kelas. (2) Kepada peneliti lain yang tertarik disarankan untuk melakukan penelitian terhadap pendekatan BLBVA pada sampel yang lebih besar dan pada materi yang lebih luas. (3) Kepada sekolah maupun dinas pendidikan terkait, hendaknya sebelum melaksanakan pembelajaran blended learning secara sistematis di sekolah masing-masing, perlu melakukan persiapan secara sungguhsungguh meliputi (a) peningkatan kapasitas infrastruktur pembelajaran online oleh sekolah, (b) meningkatkan kemampuan guru dalam mempersiapkan materi pembelajaran online seperti text, video, animasi dan sebagainya sebagai materi utama yang bisa dipelajari siswa secara online dan yang berorientasi pada pencapaian tujuan pembelajaran, dan tentunya gayut dengan pembelajaran tatap muka sebagai kelanjutan dari pembelajaran onlinenya. (c) Di samping itu, pembelajaran blended juga perlu jadikan sarana belajar bersama oleh guru-guru secara kolegial, karena itu sangat disarankan jika penerapan blended learning ini dikombinasikan dengan prinsip-prinsip lesson study.

\section{DAFTAR RUJUKAN}

Abramovitz, B., Berezina, M., Berman, A., \& Shvartsman, L. (2012). A Blended Learning Approach in Mathematics. Http://services.igi- global.com Iresolvedoi

/resolve.aspx?doi $=10.4018 / 978-1$ -

60960-875-0.ch002, 22-42.

https://doi.org/ 10.4018/978-1-

60960-875-0.ch002

Demand Forecast Ditjen Postel,. (2002).

Sekretariat Negara Republik Indonesia - Strategi dan Kebijakan

Pembangunan di Bidang

Komunikasi dan Informatika.

Retrieved November 25, 2016, from

http://www.setneg.go.id/index.php? option=

com_content $\&$ task=view\&id $=528$

\&Itemid $=11$

Hilliard, A. T. (2015). Global Blended Learning Practices for Teaching and Learning, Leadership and Professional Development. Journal of International Education Research, 11(3), 179-188.

Jakaria, M. H. D., I Gusti Putu Sudiarta, \& Gede Suweken. (2014). Pengembangan Media Pembelajaran IKRAR Berbasis Video Untuk Meningkatkan Prestasi Belajar Siswa Kelas VII. Jurnal Pendidikan Matematika, 3(1). Retrieved from http://pasca.undiksha.ac.id/ejournal/index.php/JPM/article/view $/ 1438$

Khan, S. (2013). The One World Schoolhouse: Pendidikan Kelas Dunia untuk Siapapun di manapun (I). Jakarta: Penertbit Noura Books.

Maarop, A. H., \& Embi, M. A. (2016). Implementation of Blended Learning in Higher Learning Institutions: A Review of Literature. ResearchGate, 9(3), 41. https://doi.org/10.5539/ies.v9n3p41

Pradnyawati, L. D. I., Suparta, I. N., \& Sariyasa. (2014). Pengaruh Strategi Blended Learning dalam Pembelajaran Kooperatif terhadap Motivasi Belajar Matematika Ditinjau Dari Gaya Belajar Siswa di SMPK 2 Harapan. Jurnal Pendidikan Matematika, 3(1). Retrieved from http://pasca.undiksha.ac.id/e- 


$$
\begin{aligned}
& \text { journal/ } \\
& \text { index.php/JPM/article/view/1356 }
\end{aligned}
$$

Umoh, J. B., \& Akpan, E. T. (2014).

Challenges of Blended E-Learning

Tools in Mathematics: Students'

Perspectives University of Uyo.

Journal of Education and Learning, $3(4), 60$.

Vaughan, N. D. (2010). A blended community of inquiry approach: Linking student engagement and course redesign. The Internet and Higher Education, 13(1-2), 60-65. https://doi.org/10.1016/j.iheduc.200 9.10.007

Zainuddin, Z., \& Halili, S. H. (2016). Flipped Classroom Research and Trends from Different Fields of Study. International Review of Research in Open and Distributed Learning, 17(3), 313-340. 